\title{
THREE SUCCESSFUL BROODS OF THE MOURNING DOVE IN ONE SEASON IN REGINA, SASKATCHEWAN
}

In 2009, a pair of mourning doves (Zenaida macroura) nested in a Manitoba maple (Acer negundo) tree next to our driveway, only $4.3 \mathrm{~m}$ from the railings of the steps leading into our house, in Regina, SK. This allowed me to observe them daily. I hoped to confirm some observations reported in the literature and to make new ones on the behavior of breeding mourning doves.

Mourning doves are beautiful, interesting, and now common birds in Saskatchewan. Historically, they were rare in the prairies, being restricted to river valleys. ${ }^{1,2,3}$ However, with human settlement, their population increased. ${ }^{2}$ Males and females form lifelong bonds and they nest in deciduous and evergreen trees, ${ }^{4}$ on the ground near trees, ${ }^{5,6}$ in cultivated fields, ${ }^{7}$ and in highway ditches. ${ }^{8}$ The males select the nest site and supply the nesting material, and the female builds the nest. ${ }^{4}$ Normally a pair produces two broods, but there may be four, usually with two eggs each, in southern Manitoba. ${ }^{4}$ One of the parents sits on the nest at all times with the male from about 08:30 until 16:30 h, when the female takes over. ${ }^{9}$ The incubation period is 14 days, and the young, called squabs, may leave the nest at 12 to 14 days of age. They depend on the parents for food until over 20 days of age. ${ }^{5,10}$ Both males and females feed the young, first by regurgitating digested food (called "pigeon's milk", originating from the crop wall) and then seeds. ${ }^{4,5}$ Doves are able to drink water in a continuous draught. ${ }^{5}$ Mourning doves are prodigious seed eaters. They may ingest 20 to 50 seeds per minute while feeding. ${ }^{5}$ Niven found an injured bird with the crop full of wild buckwheat and wild mustard seeds. ${ }^{11}$ Predators other than humans include hawks, owls, and cats. ${ }^{5}$ Mourning doves migrate south for the winter but are occasionally recorded in Christmas Bird Counts. ${ }^{12}$

On 25 May 2009, a pair began building their nest $3.45 \mathrm{~m}$ off the ground (Table 1). It was constructed on a large, nearly horizontal branch, next to the tree's main trunk, and flanked on the west side by an unoccupied nesting box. Initially, the doves seemed to be active at the nest site only in the morning. I was not able to distinguish the male from the female due to their secretive behaviour and the densely shaded nest. I did not approach closely, for fear of disturbing them. (As our neighbourhood is populated with freely roaming cats that could easily climb up to the nest, I set up my cat trap near the nesting tree and caught one each during the following two nights. They were turned over to the Animal Control unit of the city of Regina.) From 28 May on, one parent was sitting on the nest at all times except as noted later. On some days, I observed the 'change of guard' at about 16:30 h. At $07: 30 \mathrm{~h}$ on 13 June, I heard cooing and intensive cooing on 20 June about 08:00 h. On the same day, I saw two squabs in the nest and heard cooing with a higher and a lower pitch. It was probably a squab that cooed at the higher pitch. ${ }^{5}$ On 24 June, one young ventured out of the nest for a short while and at 19:25 h, no adult was in the nest. However, by $8: 30 \mathrm{~h}$ one adult was back on the nest. The young left the nest on 25 or 26 June.

On 1 July, again one adult was sitting on the nest. On 22 July, I confirmed that a second clutch had hatched; at least one squab was vigorously fed by an adult and on the next day I saw 2 squabs. On 25 July, there was no adult on the nest for at 
Table 1. Details of 3 broods of mourning dove observed in the same nest in Regina, SK, in 2010.

\begin{tabular}{|l|l|l|l|l|}
\hline Brood & Nest building & $\begin{array}{l}\text { Adult } \\
\text { continuously on } \\
\text { nest }\end{array}$ & $\begin{array}{l}\text { Squab(s) seen } \\
\text { on nest }\end{array}$ & Squabs left nest \\
\hline 1 & 25 May & 28 May & 20 June & 25 or 26 June \\
\hline 2 & Not observed & 1 July & 22 July & 27 July \\
\hline 3 & 29 July & 29 July & 26 August & 27 August \\
\hline
\end{tabular}

least 2 hours. In the afternoon, the young ventured out of the nest on the big, almost horizontal branch. On 27 July, they had flown the coop. I saw one young on the ground, only $14 \mathrm{~m}$ away from the nesting tree.

On the next day, one adult came with nesting material in its beak, and on 29 July, an adult was sitting on the nest again. On 22 August, I observed two squabs. On 26 August, the parents were absent from the nest quite often, and on the next day the squabs moved out of the nest onto the horizontal branch next to the nest where they were fed by a softly cooing parent. On 27 August, the two squabs had left the nest and were observed on the ground where the squab of the previous brood had sat. I observed them daily at this site, first sitting close together, then more apart every day, until 4 September. On 5 September, they flew into nearby bushes, and by 7 September they had left the area. No doves used the nest in 2010.

The mourning doves started breeding in late May, and the young of the third and final brood fledged in late August. Late May is the most common time in spring when nests with eggs are found in the Saskatoon area, and elsewhere in Saskatchewan, nests with eggs are found until mid-September. ${ }^{13}$ Each brood took almost exactly one month from the time an adult sat continuously on the nest until the young left the nest. This agrees with reports in the literature: 14 days of incubation and the young leaving the nest at 12 to 14 days of age. ${ }^{5}$ As the young do not become independent until they are about 20 days old ${ }^{5}$ the parents started the next brood while still caring for the previous one. On the days just before the squabs fledged, they were occasionally unguarded by the parents, a behaviour I did not find reported in the literature. Our mourning doves were very quiet during the nesting period, which confirms other observations, ${ }^{4}$ but they cooed frequently in the mornings of the days shortly before the squabs left the nest. I did not find evidence in the literature that fledglings spend their first days on the ground. During these days, they are probably easy prey for cats. Two squabs were seen shortly before fledging in each of the three broods. Assuming 2 eggs in each, nesting success was $100 \%$ as compared to an average of about $50 \%$ in lowa. ${ }^{5}$

\section{Acknowledgements}

I thank the editors and an unknown reviewer for many very helpful suggestions.

1. Houston CS (1986) Mourning dove numbers explode on the Canadian prairies. American Birds 40:52-54.

2. Houston CS, Houston MI (1997) Saskatchewan bird species which increased with settlement. Blue Jay: 55:90-96.

3. Smith AR (1996) Atlas of Saskatchewan Birds. Saskatchewan Natural History Society. Special Publication No. 22. No. 4 Manley Callin Series. Saskatchewan Natural History Society, Regina, SK. 
4. Bancroft J (1993) Observations on the dove family. Blue Jay 51:150-152

5. Miller WJ (1969) The biology and natural history of the mourning dove, presented at a public forum on the question "Should doves be hunted in lowa" sponsored by the Ames Audubon Society. Available online at <http://www.ringneckdove.com/ Wilmer's\%20WebPage/mourning_doves.htm>

6. Switzer F (1994) Heard but not necessarily seen: Surveys of birds at Greenwater and Moose Mountain Provincial Parks. Blue Jay 52:152-159.

7. Mann SA (1959) Mourning doves nesting in open fields. Blue Jay 17:156.

8. Oetting RB (1971) Right-of-way resources of the prairie provinces. Blue Jay 29:179-183.

9. Dennis JV (1975) Beyond the bird feeder. Alfred J. Kopf. New York. 201 pp.
10. Baicich PJ, Harrison CJO (1997) A guide to the nests, eggs, and nestlings of North American birds. $2^{\text {nd }}$ edn. Academic Press, San Diego, CA.

11. Niven W (1944) Bird notes. Blue Jay 3:25.

12. Renaud WE (1977) A review of Saskatchewan Christmas Bird Counts: 1942-1976. (Part 1) Blue Jay 35:224-239.

13. Nature Saskatchewan/Saskatoon Nature Society (2002) Birds of the Saskatoon Area. Saskatchewan Natural History Society. Special Publication No. 23. No. 5 Manley Callin Series.

- Diether P. Peschken, 2900 Rae Street, Regina, SK, S4S 1R5, E-mail: <peschken@sasktel.net>

Nature is, after all, the only book that offers important content on every page.

- Johann Wolfgang von Goethe

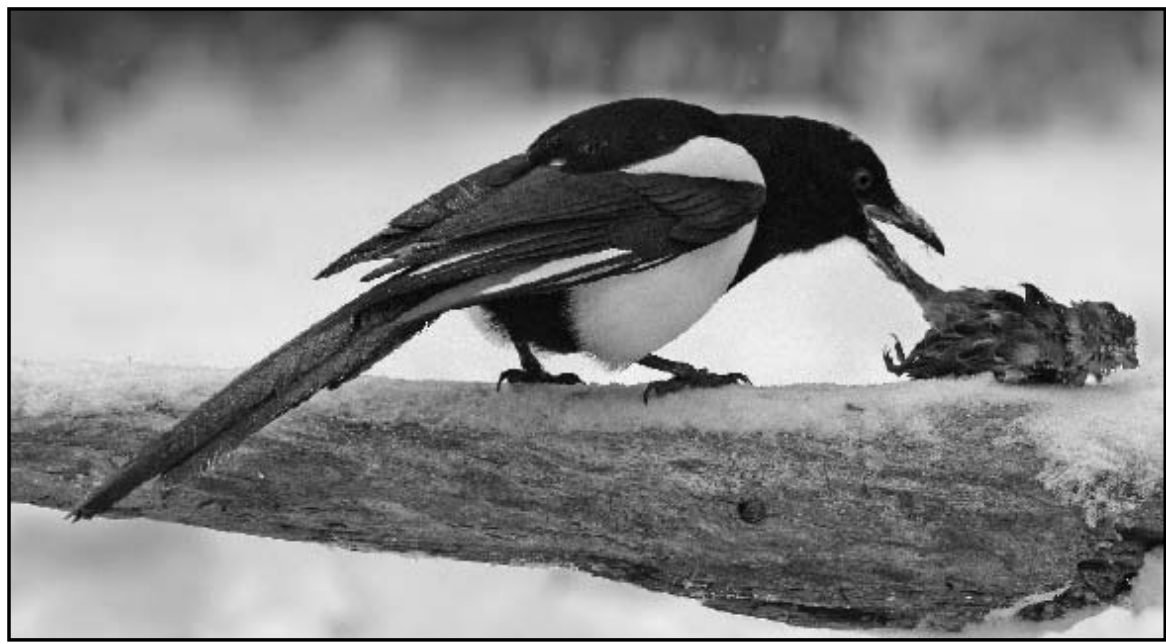

